\title{
Human Resource Development Practices: A Study of Public and Private Life Insurance Companies
}

\author{
Dr. Chandan \\ (MBA, Ph.D.)
}

\begin{abstract}
The human resource development comprises of three areas namely individual development, occupational development and organizational development. The ultimate objective of HRD is to contribute to the professional well-being, motivation and pride of the employees. The Indian insurance sector is the most dynamic sector of the Indian economy both in terms of employment potential and contribution to national income. The present paper which studies the prevailing human resource development practices of life insurers in India is two dimensional. Firstly, it portrays prevailing human resource development practices of public and private life insurers in India. Secondly, it examines the job satisfaction level of marketing functionaries working in both public and private life insurance companies. The study reveals that the public and private life insurance companies have their own HRD departments which are responsible for preparing the training and development programmes for their sales force. Further, the life insurance companies train their sales force at regular intervals of time. It is suggested that attempts should be made by life insurance companies to make harmonious relationships among office staff and marketing functionaries to boost the morale of marketing personnel which results in high level of job satisfaction.
\end{abstract}

Keywords: Human resource development, Job satisfaction, life insurers, marketing functionaries, training

\section{Introduction}

Human Resource Development is a system of developing the competencies of individual employees, teams and the organization in a continuous and planned way to achieve the organizational goals. The ultimate objective of HRD is to contribute to the professional well-being, motivation and pride of the employees. In organizations training and development begins with entry of an employee in the company and remain continuous throughout the tenure of employee. ${ }^{1}$ The job satisfaction is the core of Human Resource Developmentprogrammes designed by the organizations. The job satisfaction is how people feel about different aspects of their jobs and is the degree to which the people like or dislike their jobs ${ }^{2}$. Locke (1976) defined job satisfaction as a "pleasurable and positive emotional state resulting from appraisal of one's job or job experiences" ${ }^{\prime 3}$.The various factors responsible for job satisfaction are compensation, opportunities for promotion, working hours, support from supervisors etc. The job analysishelps in developing appropriate design of job to improve efficiency and satisfaction. The main objective of job design is to combine the needs of the individual (interest, challenge and achievement) and the requirements of the organization (high productivity, technical efficiency and quality of work). ${ }^{4}$ The life insurance companies in India aim at high job satisfaction, team work, high involvement of sales force, enhancing problem solving ability of sales force and to maintain good organizational climate through the development programmes of employees and sales force. The public and private life insurance companies have their own HRD departments which are responsible for preparing the training and development programmes for their sales force. The life insurance companies organize various programs at regular intervals to boost the morale of employees and marketing personnel which may result in high level of job satisfaction.

\section{Review Of Literature}

Agadi and Bais (2008) tried to identify and analyze the employee related problems encountered in the process of HRD in LIC. The study was based on the primary and secondary data. The study found that training did not provide any monetary and promotional benefits to the employees. The lack of training policy was also found to be prevalent in LIC. The study emphasizedon upgradingtraining related information. The study suggested

\footnotetext{
${ }^{1} \mathrm{http} / / / \mathrm{www}$.pondiuni.edu.in/sites/default/files/HRDt200813.pdf

${ }^{2} \mathrm{https} / / /$ books.google.co.in/books?id=nCkXMZjs0XcC\&printsec=frontcover\&dq=job+satisfaction\&hl=en\&sa $=$ $\mathrm{X} \&$ redir_esc $=\mathrm{y} \# \mathrm{v}=$ onepage $\& \mathrm{q}=\mathrm{job} \% 20$ satisfa $\quad$ ction $\& \mathrm{f}=\mathrm{false}$

${ }^{3}$ https://books.google.co.in/books?id=4IdbmX4pDpkC\&pg=PA180\&dq=job+satisfaction+definition\&hl=en\&sa $=X \& v e d=0$ ahUKEwjk2au4n6nTAhVMpo8KHXlrC2oQ6AEIQzAG\#v=onepage \&q=job\%20satisfaction\%20def inition\& $\mathrm{f}=$ false

${ }^{4}$ archive.mu.ac.in/myweb_test/M.Com. Study Material/Human Res. Management - M. Com - I.pdf

DOI: $10.9790 / 487 \mathrm{X}-1906021021$

www.iosrjournals.org

$10 \mid$ Page
} 
thatreading material should be handed over to employees in advance to give themsufficient time to go through the material andhelp them to participate effectively in the discussions.

Bais (2011) studied existing HRD climate, policy of training and development and effectiveness and instruments used to appraise the performance of the employees in LIC.The study revealed that training practices in LIC were inadequate and suffered from certain weaknesses. The performance appraisal was also irregular. It suffered from superiors' favoritism, prejudices and biases vague performance standards etc. Majority of the employees were not happy with remuneration and retirement benefits. The study suggested that the personnel policies regarding placement, promotion, training and development should be implemented in a flexible manner. Patre and Gawande (2012)studied the level of job satisfaction and intent to leave the job among sales force of private sector insurance companies. The study was based on the opinion of 225 salesmen of 12 private insurance companies in Nagpur city. The study revealed that job satisfaction level of the sales force in insurance companies was neither too high nor too low on five point rating scale. The respondents showed moderate level of intention to leave their job. The study suggested that the insurance companies should try to increase the satisfaction level of their employees on various parameters. This would help them increase the intention of employees to stay in their organization and thus control their attrition rate.

Kaur (2012) in her paper studiedjob satisfaction level of employees of public and private insurance companies in Punjab. The study concluded that income was directly related with job satisfaction. The private sector employees were found to be highly satisfied with the income and training as compared to public sector employees.

Singh (2012) studied the job satisfaction in top ten players of private insurance sector in Uttar Pradesh. The study was based on primary data. The study revealed that employees liked to work for organizations which could provide them an excellent work culture, an attractive performance based pay package and growth opportunities.

Yadav et al. (2014)in their papermeasured the satisfaction level of employees of HDFC Standard life Insurance Company and tried to find outthe factors responsible for job satisfaction. The study was based on primary data collected from 40 employees of Napier Town, Jabalpur Branch of Madhya Pradesh. The study found that employees were satisfied with their salaries and growth opportunitiesbut less supportive working environment etc. led to dissatisfaction among employees. The study suggested that the company should givetimely promotion to the deserving employees.

Tiwari (2014) assessed the level of job satisfaction among the employees of LIC working inRewa and Satna division of Madhya Pradesh. The study showed that job satisfaction had good impact on employees' performance. The factors like convenient working hours, fairness and participation in decision and chances for future development increased overall satisfaction of employees. The study suggested that attractive and competitive pay package along withexcellent career opportunitiesshould be provided to the potential workforce. Thetransparent performance appraisal system should be opted by LIC was another sugestion

Dolai (2015) analyzed the HRD Climate of the public and private sector insurance companies and found that the overall development of organization was dependent on its HRD climate and culture. The study revealed that the HRD Climate of the public sector insurance company was much better than that of the private sector insurance companies.

Dash and Das (2016) studied HRD climate prevailing in the LIC of India and satisfaction level of employees regarding the prevailing HRD climate in their organization. The study found that the employees were fairly satisfied with the top management initiatives but they were somewhat dissatisfied with the employees relationships. The study suggested that superior officers should show more personal interest in the development of their subordinates. Various team building exercises should be implemented to increase the team spirit of the employees. Moreover, informal functions, holiday celebrations, birthday celebrations, informal get-to-gathers, picnics etc. should be organized in organization to improve employee relationships.

\section{Objectives of the study}

1. To study the prevailing human resource development practices of public and private life insurance companies operating in India.

2. To identify the different methodspreferably adopted by life insurance companies to train the sales force.

3. To examine the awareness level of marketing functionaries regarding use of outside agenciesfor training of sales force by life insurance companies.

4. To study the level of job satisfaction among marketing functionaries resulting from prevailing human resource development practices of public and private sector life insurance companies.

\section{Scope of the Study}

The scope of study is limited to public and private sector life insurance companies. 


\section{Research Methodology}

The present study is based on secondary and primary data. The secondary data have been collected from various sources namely Annual Reports of IRDAI and Annual Reports of selected public and private life insurance companies operating in India. The study has also used some relevant information from the website of Insurance Regulatory and Development Authority of India (IRDAI). The primary data pertain to public sector life insurance Company (LIC) and 3 major private life insurance companies operating in Punjab. These life insurance companies are ICICI Prudential Life Insurance Company Limited, Bajaj Allianz Life Insurance Company and HDFC Standard Life insurance company. The individual agents have been considered as a unit of investigation. A sample of 200 agents (100 from public sector life insurance company (LIC) and 100 from 3 selected private life insurance companies) spread over four districts of Punjab namely Ludhiana, Amritsar, Jalandhar and Patiala representing all the belts of Punjab namely Malwa, Doaba and Majha regions has been taken.

\section{Reliability and Validity Analysis}

To collect primary data a comprehensive questionnaire was prepared. The questionnaire was pre-tested on 20 respondents (10 each from the private and public sector life insurance companies). To test the reliability of the scale used in study, the value of Cronbach's alphawas calculated. The calculated value ofCronbach's alpha for public sector $(0.828)$ and private sector $(0.898)$ respondents regarding job satisfaction is found to be above the acceptable level of 0.70 (George and Mallery 2003). Thecalculated value of Cronbach's alpha for respondents of both the sectors taken together (0.881)shows that there is high internal consistency among items. In the light of results of reliability test and opinion of experts oncontent and face validity of scale, the final questionnaire was prepared. The results of reliability test (Cronbach's alpha) are presented in Table 1.

Table 1: Results of Reliability Test Regarding Level of Job Satisfaction of Marketing Functionaries

\begin{tabular}{|l|l|l|}
\hline Sector & Number of Items & Calculated Value of Cronbach's alpha \\
\hline Public & 8 & 0.828 \\
\hline Private & 8 & 0.898 \\
\hline Both & 8 & 0.881 \\
\hline
\end{tabular}

\section{Data Analysis And Statistical Techniques}

The personal interview method was used to collect information from sampled respondents. The educationalqualification wise, experience-wise and sector-wise analyses have been carried out. The weighted average scores have been computed on the basis of frequency of rating for each attribute. The educational qualification, experience and sector-wise weighted average scores have been computed by assigning weights as +2 , for highly satisfied +1 for satisfied, 0 for neutral, -1 for dissatisfied and -2 for strongly dissatisfied.The Shapiro Wilks Normality test has been applied to determine whether the variables are normally distributed for each combination levels. The condition of normality is not met with each combination levels. The output of Quantile-quantile plot (Q-Q plot) also confirms the same as all data points are not close to the diagonal straight line.Thus to sharpen the inferences drawn on the basis of description of facts in terms of frequencies, percentages and averages, non-parametric tests have also been used at appropriate places. In order to test the association between opinions of respondents on certain attributes, the Chi-square test has been applied. To test statistical association based on the ranking of data between public and private sector respondents on attributes of job satisfaction, the Kendall Rank Correlation Coefficient which is commonly referred as Kendall's Tau Coefficient has been applied.To test theconcurrence of rankings among the respondents from various categories ofeducationalqualification and experience, the Kendall's Coefficient of Concordance has been applied.The main hypotheses have been formulated at appropriate places of the study and accepted or rejected at 5 per cent level of significance by applying suitable tests. The respondents are also asked to assign ranks to different methods adopted by life insurance companies for the training of sales forceaccording to their usage and popularity. These order of merit given by respondents are converted into per cent position through following formula

\section{Where}

Percent position $=\frac{100(R i j-0.5)}{N j}$

$\mathrm{Rij}=$ Rank given for the ith variable by jth respondents

$\mathrm{Nj}=$ Number of variable ranked by jth respondents

The obtained percentage position of each rank is converted into scores by using table given by Henry Garret. Then for each method of trainingthe scores of individual respondents are added and mean score is calculated for each method of training. The methods of training are then ranked according to the mean score and then on the bases of ranks inferences are drawn. 


\section{Human Resource Development Practices}

Human Resource Development focuses on enhancing learning culture in the life insurance companies. The life insurance companies in India aim at high job satisfaction, team work, high involvement of sales force, enhancing problem solving ability of sales force and to maintain good organizational climate through the development programmes of employees. The public and private life insurance companies have their own HRD departments which are responsible for preparing the training and development programmes for their sales force. The Human Resource Development practices of public and private life insurers are discussed below.

\section{(A) Human Resource Development Practices of Public Sector Life Insurance Company (LIC)}

The HRD department of LIC plays a vital role in enhancing the performance of sales force to achieve and maintain the competitive advantage of the organization. LIC tries to maintain cordial and harmonious relations among employees. Training is provided through various programmes to upgrade the competences and skills of sales force.LIC has its own training centers where officers are posted as faculty. The services of external trainers are also used to update the sales force on recent changes occurring in the market. To train faculty members "Train the trainer" progrmme is conducted by the company. In LIC top development officers are sent to various management institutes of the country such as Indian Institute of Management Lukhnow, for Management Development Progrmme. The Million Dollar Round Table (MDRT) agents are sent to Management Development Institute (MDI) Gurgaon for two days specialized training on Management Development Progrmme. Management Development Centre (MDC) is the apex training center of the Life Insurance Corporation which plays a leading role in sharpeningthe skills of the middle and senior administrative and marketing officers of LIC. It is an IS/ISO 9001:2008 Certified Training Centre. The various programmes conducted at MDC in the last few yearsare given in Table 2.

Table 2reveals that 122 programmes are conducted by MDC to train 3107 officials during 2015-16 registering a growth of 10 and 11 per cent respectively over a previous year in terms of programmes and number of officials.

Table 2: Overview of Programmes conducted at MDC

\begin{tabular}{|l|l|l|l|l|}
\hline Nature of Training Programme & $\mathbf{2 0 1 4 - 1 5}$ & $\mathbf{2 0 1 5 - 1 6}$ \\
\cline { 2 - 5 } & $\begin{array}{l}\text { Number of } \\
\text { Programmes }\end{array}$ & $\begin{array}{l}\text { Number of } \\
\text { Participants }\end{array}$ & $\begin{array}{l}\text { Number } \\
\text { Programmes }\end{array}$ & $\begin{array}{l}\text { Number } \\
\text { Participants }\end{array}$ \\
\hline $\begin{array}{l}\text { Training for Marketing and Sales Staff } \\
\text { Including Inductions }\end{array}$ & 17 & 476 & 18 & 526 \\
\hline Functional Induction Programmes & 21 & 475 & 29 & 783 \\
\hline Train the Trainer Programmes & 2 & 62 & 1 & 26 \\
\hline Special Programmes & 68 & 85 & 73 & 1746 \\
\hline $\begin{array}{l}\text { Other Programmes including AAO's } \\
\text { Induction }\end{array}$ & 3 & 1698 & 26 \\
\hline Total & 111 & 2796 & 122 & 3107 \\
\hline
\end{tabular}

Source: Annual Report of LIC for respective years.

The Development officers (non SBAs) are also given specialized training through external training institutes like IIST Pune, Data Comp, JivanVidya Trust (JVT) etc. The induction trainings are conducted by LIC for newly appointed agents across the country. "ShaktimaankiUdaan" is an induction program organized by LIC for assistant sales managers. The customized Progrmme on "Business Leadership" is conducted by School of Business Hyderabad. The functional training is also provided to class 1 and class 3 employees of the organization. LIC has focused on strengthening performance of people by improving its training process during 2015-16.LIC has also won the Golden Peacock Award for HR Excellence in Training for the year 2016.Moreover, the agents are also given loans under Agent Housing scheme. LIC has sanctioned 41.29 crores of loans during 2015-16 under Agent Housing scheme. The company has well designed performance appraisal system to appraise the performance of its employees on regular basis. The details of training conducted during 2015-16 by LIC for field force are given in Table3.

Table 3:Training Details of Field Force during 2015-16

\begin{tabular}{|l|l|l|l|l|l|}
\hline Target Group & $\begin{array}{l}\text { External Training } \\
\text { Institutes }\end{array}$ & $\begin{array}{l}\text { Zonal Training } \\
\text { Centre }\end{array}$ & $\begin{array}{l}\text { Sales Training } \\
\text { Centre }\end{array}$ & New agents' Induction & Total \\
\hline $\begin{array}{l}\text { Development } \\
\text { Officers }\end{array}$ & 5137 & 2078 & 6257 & 00 & 13472 \\
$(15.42)$ & 11751 & $100)$ & $(0.00)$ \\
\hline $\begin{array}{l}\text { Agents and other } \\
\text { channels }\end{array}$ & $(38.13)$ & $(5.98)$ & $(55.06)$ & 68489 & $(34.84)$ \\
\hline Total & $(4.13)$ & 13829 & 114492 & 68489 & $(100)$ \\
& 13255 & $(6.58)$ & $(54.50)$ & 210065 \\
$(100)$
\end{tabular}

Annual Report of LIC 2015-16. 
Figures in parenthesis are percentages

The above table depicts that 5137Development Officers, 8118 agents and representatives of other channels were trained by External Training Institutes. The total of 2078 Development officers and 11751 agents and representatives of other channels were trained by Zonal Training Centres of LIC. Nearly 6257 Development Officers and 108235 agents and representatives of other channels got Training at Sales Training Centers of LIC. A large number of agents got induction training (68489) during 2015-16. Further, of the development officers 38.13 per cent were trained by External Training Institutes and 46.44 per cent by the sales training center of LIC. The Zonal training center trained only 15.42 per cent of thedevelopment officers. In case of agents and others the most important training center seems is sales training center (55.06) followed by new agent's induction (34.84).

\section{(B) Human Resource Development Practices of Private Life Insurance Companies}

To improve the quality of sales force in future HDFC Life insurance Company Limited has also introduced Smart Achievers Programme to create a professionalized workforce at sales entry level by encouraging the development of future leaders and for ensuring a talent in future for frontline Sales force. HDFC Life has launched a programme in association with Manipal Global Education Services Pvt. Ltd that ensures a strong talent pool via classroom training on Manipal Campus, backed by on-the-job training and internship at HDFC Life offices across the country. The selected students who are enrolled in the programme are awarded a degree of Post Graduate Diploma in Insurance from Manipal University and guaranteed job in HDFC Life. The company has also made arrangements with various Institutes or Universities for conducting Insurance courses for frontline sales force. The Indian School of Business (ISB), Hyderabad is also engaged by the company to provide management development programmes. To improve satisfaction among employees the senior leadership of the company tries to listen to their employees through various platforms like Employee Engagement Survey, Sparsh, Coffee with Leadership and branch visits of value champions. The study conducted by the Great Places to Work Institute has placed HDFC Life Insurance Company Limited among top 50 best places to work in 2014. The company has received Asia Best Employer Brand Awards 2013 and Golden Peacock HR Excellence award 2013. Whistle Blower Policy of the company tries to provide the employees a channel for communicating any breaches of the Company's Values, Code of Conduct, Anti-Money Laundering Policy and other regulatory and statutory requirements. The appropriate and strong action is taken against any violation of Company's Values and Code of Conduct etc. The Risk Management Committee, in its periodical meetings, is informed on the whistle blower cases. In case of any significant matter the same is informed to the Board. For prevention of sexual harassment an Apex Committee headed by a senior woman executive is also formed in the company. The Committee also comprises a senior independent woman member and expert on the subject matter. The Risk Committee of the Board also gets updates periodically on matters relating to Sexual Harassment Policy as well as on the incidents, if any.

In ICICI Prudential Life Insurance Company, the sales force is given challenging assignments and also follow job rotation to give learning experience to agents. It provides varied spectrum of self-directed learning opportunities through e-learning programmes, newsletters and online repository library. Learning events and workshops are conducted from time to time. The company aims at long term career proposition by providing supportive work environment and providing a platform for the growth of sales force. Recently the company has organized CEO Convention in which ground level employees were able to connect with Chief Executive Officer to boost the morale of employees. The company has also given tablets to its sales force. This helps them not to bind by office hours to give solution to customers. The company provides regular training to develop soft skills, process knowledge and understanding of regulatory requirements for the front line staff. Company ensures that the sales teams attend the grievance module once in six months. Training programs related to policyholders' protection and to enhance knowledge on regulatory framework are provided by the Company through face to face trainings or e-learning modules. The company has formulated a Whistle Blower Policy to encourage employees to report matters. As per the Policy, employees can raise concerns related to breach of any law, statute or regulation, issues related to accounting policies and procedures, Acts resulting in financial loss or loss of reputation, misuse of office, suspected/actual fraud and criminal offences, non-compliance to anti-bribery and anti-corruption policy by the Company or its employees to the Board Audit Committee through specified channels. The Company has laid down policy on sexual harassment at work place and has informed all its employees about the same. The Company conducts seminars in the organization to create awareness among its employees The Company also sends its employees for various seminars or discussion forums.

Bajaj Allianz Life Insurance Company Limited provides 'on the job' training to its employees. The Company provides the cross functional opportunities to its employees by providing internal job postings to enable them to learn new skills and use their acquired skills successfully. The company has also bi-annual performance appraisal system. The company provides frequent newsletters to the employees so that they are able to know various activities of organization. The company provides Employee Helpdesk for any medical 
emergency. The offices of the company are adapted to health, safety, security and environmental standards. The Company provides safe and secure work environment to all employees. The company also helps the employees by formulating travel policies and guidelines on personal safety during travel. Through programmes like Coffee with CEO, Town-halls or Open house sessions the company tries to connect senior leadership with the employees. The company also provides management trainee program for sales force and employees to produce leaders for future. Recently the company has celeberated its $14^{\text {th }}$ Annual Day (jashan) in which the company has honored the employees for their special achievements. The vintage employees who have completed 10 years of service in the company has also been congratulated by the company. The company uses various platforms like 'Feedback Drive', and 'Focused Group Discussion' to get insights for developing employee welfare schemes. The company has created various learning programmes for employees such as 'SWAT - teams set to drive projects of innovation, 'Shubharambh - A New Joinee Induction Program'The Company has also formed a Whistle Blowing Committee for the employees. The company has given certain platforms like 'Mann Ki Baat HOD keSath' in which staff and sales personnel can freelyinteract with higher officials. The company has also introduced a mobile application called'I am BALIC' to share HR related services with employees and sales force. The Audit Committee of the company is responsible for proper functioning of this mechanism. The employees can report about possible irregularities, governance weaknesses, financial reporting issues or other such matters of irregularities. In appropriate cases the concerned person may approach the Chairperson of the Audit Committee.

\section{Methods of Training in Life Insurance Industry}

Training is one of the most important functions of sales management. A well trained and dedicated sales-force is considered as a valuable asset for the organization. In response to query whether training is needed in life insurance sector or not, around 80 to 90 per cent of the respondents from both the sectors have opined that training is required in life insurance sector. Further,the respondents are asked to rank preferred methods of training in life insurance industry. The Garret Ranking technique is used to find out most preferred and popular method of training. The total score and mean score of each method of training is calculated by using Garret formula and presented in Table 4

Table 4 depicts that the life insurance companies preferably train their sales personnel by providing them study material (mean score $=60.72$ ) at frequent intervals of time. This study material includes recent developments in the industry. The lectures in the class room commonlyreferred to as class room training (mean score $=59.22$ ) is another popular method of training in the industry. It is also seen from the same table that sometimes the life insurance companies give case studies to the sales personnel and ask them to give solution to the problems in the case studies. This method helps in improving problem solving and decision making ability of sales force. The role playing activity is least adopted method of training in life insurance industry.

Educational qualification and experience-wise total score and mean score of each method of training is calculated by using Garret formula and are given in Table 5.

Table 5 reveals that irrespective of educational qualification, the respondents have opined that lectures in class room and providing study material to the trainers are most preferred methods of training in life insurance industry. The role playing activities case studies and conferences are also organized in life insurance companies to train the sales force. Experience-wise, irrespective of experience the respondents feel that providing study material (mean score for $E_{1}=61.40$ and mean score for $E_{2}=60.47$ and mean score for $E_{3}=66.96$ ) is most preferred method of training. The lectures in class room commonly referred to as class room training followed by conferences and case studies are also preferred methods of training in life insurance industry.

Table 4: Methods of Training Used in Life Insurance Industry through Garret Ranking

\begin{tabular}{|c|c|c|c|c|c|c|c|c|c|c|c|c|c|}
\hline \multirow{2}{*}{$\begin{array}{l}\text { Methods of } \\
\text { Training }\end{array}$} & \multicolumn{10}{|l|}{ Ranks } & \multirow{2}{*}{$\begin{array}{l}\text { Total } \\
\text { Score }\end{array}$} & \multirow{2}{*}{$\begin{array}{l}\text { Mean } \\
\text { Score }\end{array}$} & \multirow{2}{*}{ Rank } \\
\hline & frequency & $\begin{array}{l}\text { Frequency } \\
\times \text { Garret } \\
\text { score }\end{array}$ & frequency & $\begin{array}{l}\text { Frequency } \\
\times \text { Garret } \\
\text { score } \\
\end{array}$ & frequency & $\begin{array}{l}\text { Frequency } \\
\times \text { Garret } \\
\text { score } \\
\end{array}$ & frequency & $\begin{array}{l}\text { Frequency } \\
\times \text { Garret } \\
\text { score }\end{array}$ & frequency & $\begin{array}{l}\text { Frequency } \\
\times \quad \text { Garret } \\
\text { score }\end{array}$ & & & \\
\hline $\begin{array}{l}\text { Class Room } \\
\text { Training }\end{array}$ & 81 & 6075 & 53 & 3180 & 35 & 1750 & 16 & 480 & 15 & 360 & 11845 & 59.22 & 2 \\
\hline Case studies & 15 & 1125 & 73 & 4380 & 42 & 2100 & 30 & 1200 & 40 & 960 & 9765 & 48.82 & 3 \\
\hline $\begin{array}{l}\text { Role } \\
\text { playing }\end{array}$ & 13 & 975 & 48 & 2880 & 64 & 3200 & 19 & 760 & 56 & 1344 & 9159 & 45.79 & 5 \\
\hline
\end{tabular}

Source: Primary Data 
Table 5: Educational Qualification and Experience-wise opinion of Respondents through Garret Ranking RegardingMethods of Training Used in Life Insurance Industry

\begin{tabular}{|c|c|c|c|c|c|c|c|c|c|c|c|c|c|c|c|c|c|c|}
\hline \multirow[t]{2}{*}{$\begin{array}{l}\text { Methods of } \\
\text { Training }\end{array}$} & \multicolumn{3}{|c|}{$\begin{array}{l}\text { Under Graduate } \\
Q_{1} \\
\text { (19 Respondents) }\end{array}$} & \multicolumn{3}{|c|}{$\begin{array}{l}\text { Graduate } \\
\mathrm{Q}_{2} \\
\text { (109 Respondents) }\end{array}$} & \multicolumn{3}{|c|}{$\begin{array}{l}\text { Post-Graduation or } \\
\text { ProfessionalQ } \\
\text { (72 Respondents) }\end{array}$} & \multicolumn{3}{|c|}{$\begin{array}{l}1-3 \\
E_{1} \\
\text { (34 Respondents) }\end{array}$} & \multicolumn{3}{|c|}{$\begin{array}{l}3-5 \\
E_{2} \\
\text { (59 Respondents) } \\
\end{array}$} & \multicolumn{3}{|c|}{$\begin{array}{l}5 \text { and above } \\
E_{3} \\
\text { (107 Respondents) }\end{array}$} \\
\hline & $\begin{array}{l}\text { Tota } \\
1 \\
\text { Scor } \\
\mathrm{e}\end{array}$ & $\begin{array}{l}\text { Mea } \\
\text { n } \\
\text { Scor } \\
\mathrm{e}\end{array}$ & $\begin{array}{l}\text { Ran } \\
\mathrm{k}\end{array}$ & $\begin{array}{l}\text { Tota } \\
1 \\
\text { Scor } \\
\mathrm{e}\end{array}$ & $\begin{array}{l}\text { Mean } \\
\text { Score }\end{array}$ & $\begin{array}{l}\text { Ran } \\
\mathrm{k}\end{array}$ & $\begin{array}{l}\text { Tota } \\
1 \\
\text { Scor } \\
\mathrm{e}\end{array}$ & \begin{tabular}{|l|} 
Mea \\
n \\
Scor \\
$\mathrm{e}$ \\
\end{tabular} & $\begin{array}{l}\text { Ran } \\
\mathrm{k}\end{array}$ & $\begin{array}{l}\text { Tota } \\
1 \\
\text { Scor } \\
\mathrm{e}\end{array}$ & $\begin{array}{l}\text { Mean } \\
\text { Score }\end{array}$ & $\begin{array}{l}\text { Ran } \\
\mathrm{k}\end{array}$ & $\begin{array}{l}\text { Tota } \\
1 \\
\text { Scor } \\
\mathrm{e}\end{array}$ & $\begin{array}{l}\text { Mea } \\
\text { n } \\
\text { Scor } \\
\mathrm{e}\end{array}$ & $\begin{array}{l}\text { Ran } \\
\mathrm{k}\end{array}$ & $\begin{array}{l}\text { Total } \\
\text { Scor } \\
\mathrm{e}\end{array}$ & $\begin{array}{l}\text { Mea } \\
\mathrm{n} \\
\text { Scor } \\
\mathrm{e} \\
\end{array}$ & $\begin{array}{l}\text { Ran } \\
\mathrm{k}\end{array}$ \\
\hline $\begin{array}{l}\text { Class Room } \\
\text { Training }\end{array}$ & 1022 & $\begin{array}{l}53.7 \\
8 \\
\end{array}$ & 2 & 7293 & 66.90 & 1 & 3690 & $\begin{array}{l}51.2 \\
5 \\
\end{array}$ & 2 & 1866 & 54.88 & 2 & 2915 & $\begin{array}{l}49.4 \\
0 \\
\end{array}$ & 3 & 6659 & 62.23 & 2 \\
\hline Conferences & 896 & $\begin{array}{l}47.1 \\
5 \\
\end{array}$ & 4 & 5661 & 51.93 & 5 & 2615 & $\begin{array}{l}36.3 \\
1 \\
\end{array}$ & 3 & 1468 & 43.17 & 5 & 3423 & $\begin{array}{l}58.0 \\
1 \\
\end{array}$ & 2 & 5510 & 51.49 & 4 \\
\hline $\begin{array}{l}\text { Study } \\
\text { material }\end{array}$ & 1299 & $\begin{array}{l}68.3 \\
6 \\
\end{array}$ & 1 & 6273 & 57.55 & 2 & 4573 & $\begin{array}{l}63.5 \\
1 \\
\end{array}$ & 1 & 2090 & 61.40 & 1 & 3568 & $\begin{array}{l}60.4 \\
7 \\
\end{array}$ & 1 & 7165 & 66.96 & 1 \\
\hline Case studies & 675 & $\begin{array}{l}35.5 \\
2\end{array}$ & 5 & 5830 & 53.48 & 4 & 675 & 9.37 & 5 & 1684 & 49.52 & 3 & 2908 & $\begin{array}{l}49.2 \\
8\end{array}$ & 4 & 5788 & 54.09 & 3 \\
\hline Role playing & 948 & $\begin{array}{l}49.8 \\
9\end{array}$ & 3 & 5930 & 54.40 & 3 & 948 & $\begin{array}{l}13.1 \\
7 \\
\end{array}$ & 4 & 1588 & 46.70 & 4 & 1876 & $\begin{array}{l}31.7 \\
9\end{array}$ & 5 & 5452 & 50.95 & 5 \\
\hline
\end{tabular}

Sector-wise total score and mean score of each method of training is calculated by using Garret formula and presented in Table 6.

Table 6: Sector-Wise opinion of Respondents through Garret Ranking Regarding Methods of Training Used in Life Insurance Industry

\begin{tabular}{|l|l|l|l|l|l|l|}
\hline \multirow{2}{*}{ Methods of Training } & \multicolumn{4}{l|}{ Public Sector } & \multicolumn{2}{l|}{ Private Sector } \\
\cline { 2 - 7 } & Total Score & Mean Score & Rank & Total Score & Mean Score & Rank \\
\hline Class Room Training & 6411 & 64.11 & 2 & 5594 & 55.94 & 2 \\
\hline Conferences & 5490 & 54.90 & 3 & 3682 & 36.82 & 5 \\
\hline Study material & 6536 & 65.36 & 1 & 5609 & 56.09 & 4 \\
\hline Case studies & 5179 & 51.79 & 4 & 4546 & 45.46 & 3 \\
\hline Role playing & 4586 & 45.86 & 5 & 4573 & 45.73 & 4 \\
\hline
\end{tabular}

Source: Primary data

Table 6 clearly shows that supply of study material in which recent developments of industry and particular company and sector is included is most preferred method of training in both public and private sector (mean score for public sector=65.36 and mean score for private sector=56.09). The lectures in class rooms to trainers(mean score for public sector=64.11 and mean score for private sector=55.94)is alsoanother used method of training in both public and private sector. The conferences (mean score for public sector=54.90)are also organized frequently in public sector for training of the respondents. The least popular method in public sector is the method of role playing (mean score $=45.86)$. In the private sector the least adopted method of training is conferences $($ mean score $=36.82)$.

\section{Awareness among Marketing Functionaries Regarding Use of Outside Agencies in Training}

Sincethe public and private life insurers in India use the services of external trainers to update the sales force on recent changes occurring in the market, it is important to examine whether themarketing functionaries working in the life insurance industry are aware regarding the use of outside agencies in their training?. The respondents were asked to record whether their company engages any outside agency for training? Their responses are given in Table 7. It is seen from Table 7, a high proportion of the respondents $(67.00 \%)$ are not aware of the participation of outside agency in training.

Table: 7 Sector-wise Awareness of Respondents Regarding Use of Outside Agency in Training $\mathbf{N}=\mathbf{2 0 0}$

\begin{tabular}{|l|l|l|l|}
\hline \multirow{2}{*}{ Aware } & Sector & Private & Total \\
\cline { 2 - 4 } & Public & 11 & 66 \\
& 55 & $(11.00)$ & $(33.00)$ \\
\hline Yes & $(55.00)$ & 89 & 134 \\
& 45 & $(89.00)$ & $(67.00)$ \\
\hline Grand Total & $(45.00)$ & 100 & 200 \\
& 100 & $(100.00)$ & $(100.00)$ \\
\hline Calculated value of & $(100.00)$ & $\mathbf{4 3 . 7 8}$ & \\
Chi-square & Degrees of freedom= 1 & & \\
& Critical value= 3.84 significant at 5 per cent level of significance \\
\hline
\end{tabular}

Source: Primary Data

Figures in parenthesis are percentages

DOI: $10.9790 / 487 \mathrm{X}-1906021021$

www.iosrjournals.org

$16 \mid$ Page 
Sector-wise analysis depicts that a high proportion of the respondents from the public sector $(65.00 \%)$ and a very small proportion from the private sector $(11.00 \%)$ are aware of the participation of any agency in training. To test that no significantdifference exists between the awareness level of the respondents of the public and private sector, the chi-square test has been applied. The calculated value of chi-square $\left(\chi^{2}=43.78\right)$ states that there is a significant difference in awareness levelbetween public and private sector respondents on the issue of participation of outside agency in training.

When the responses of marketing functionaries are classified according to their educational qualification, it is seen (table 8) that more than half of the respondents $(52.63 \%)$ in the $\mathrm{Q}_{1}$ category are aware of the participation of any agency in training. However, majority of the respondents (53.21\%) in educational qualification category $\mathrm{Q}_{2}$ are not aware of the participation of any agency in training. Moreover, an overwhelming majority of the respondents $(93.06 \%)$ in educational qualification category $\mathrm{Q}_{3}$ are not aware of the participation of any agency in training. To test that no significant difference exists among the respondents of the various educational qualification categories, the chi-square test has been applied. The calculated value of chi-square $\left(\chi^{2}=34.79\right)$ states that there is a significant difference in awareness among respondents of differentcategories of educational qualification on the issue of participation of outside agency in training

Table: 8 Educational Qualification and Experience-Wise Awareness of Respondents Regarding Use of Outside Agency in Training $\mathbf{N}=\mathbf{2 0 0}$

\begin{tabular}{|c|c|c|c|c|}
\hline Variables & Categories & Yes & No & Total \\
\hline \multirow{4}{*}{ 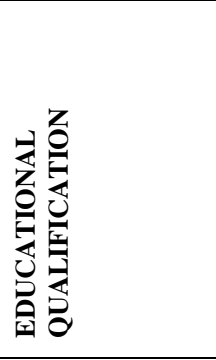 } & $\begin{array}{l}\text { Under Graduate } \\
\mathrm{Q}_{1} \\
\text { (19 Respondents) }\end{array}$ & $\begin{array}{l}10 \\
(52.63)\end{array}$ & $\begin{array}{l}9 \\
(47.37)\end{array}$ & $\begin{array}{l}19 \\
(100.00)\end{array}$ \\
\hline & $\begin{array}{l}\text { Graduation } \\
\mathrm{Q}_{2} \\
\text { (109 Respondents) }\end{array}$ & $\begin{array}{l}51 \\
(46.79)\end{array}$ & $\begin{array}{l}58 \\
(53.21)\end{array}$ & $\begin{array}{l}109 \\
(100.00)\end{array}$ \\
\hline & $\begin{array}{l}\text { Post-Graduation or Professional } \\
\mathrm{Q}_{3} \\
\text { (72 Respondents) }\end{array}$ & $\begin{array}{l}5 \\
(6.94)\end{array}$ & $\begin{array}{l}67 \\
(93.06)\end{array}$ & $\begin{array}{l}72 \\
(100.00)\end{array}$ \\
\hline & $\begin{array}{l}\text { Grand } \\
\text { Total }\end{array}$ & $\begin{array}{l}66 \\
(100.00) \\
\end{array}$ & $\begin{array}{l}134 \\
(100.00) \\
\end{array}$ & $\begin{array}{l}200 \\
(100.00) \\
\end{array}$ \\
\hline \multicolumn{2}{|c|}{ Calculated Value of Chi-square } & \multicolumn{2}{|c|}{$\begin{array}{l}34.79 \\
\text { Degrees of freedom }=2 \\
\text { Critical value }=5.99 \\
\text { significant at } 5 \text { per cent level of significance }\end{array}$} & \\
\hline \multirow{4}{*}{ 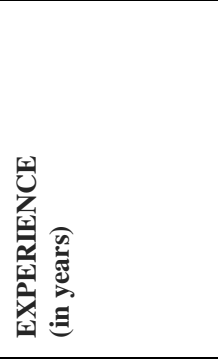 } & $\begin{array}{l}1-3 \\
E_{1} \\
\text { (34 Respondents) }\end{array}$ & $\begin{array}{l}19 \\
(55.88)\end{array}$ & $\begin{array}{l}15 \\
(44.12)\end{array}$ & $\begin{array}{l}34 \\
(100.00)\end{array}$ \\
\hline & $\begin{array}{l}3-5 \\
\mathrm{E}_{2} \\
\text { (59 Respondents) }\end{array}$ & $\begin{array}{l}42 \\
(71.19)\end{array}$ & $\begin{array}{l}17 \\
(28.81)\end{array}$ & $\begin{array}{l}59 \\
(100.00)\end{array}$ \\
\hline & $\begin{array}{l}5 \text { and above } \\
E_{3} \\
\text { (107 Respondents) }\end{array}$ & $\begin{array}{l}5 \\
(4.67)\end{array}$ & $\begin{array}{l}102 \\
(95.33)\end{array}$ & $\begin{array}{l}107 \\
(100.00)\end{array}$ \\
\hline & $\begin{array}{l}\text { Grand } \\
\text { Total }\end{array}$ & $\begin{array}{l}66 \\
(100.00) \\
\end{array}$ & $\begin{array}{l}134 \\
(100.00)\end{array}$ & $\begin{array}{l}200 \\
(100.00)\end{array}$ \\
\hline $\begin{array}{l}\text { Calculated } \\
\text { Value of Chi- } \\
\text { square }\end{array}$ & \multicolumn{3}{|c|}{$\begin{array}{l}85.79 \\
\text { Degrees of freedom }=2 \\
\text { Critical value }=5.99 \\
\text { significant at } 5 \text { per cent level of significance }\end{array}$} & \\
\hline
\end{tabular}

Source: Primary Survey

Figures in parenthesis are percentages

The responses are also classified according to experience of respondents and are also presented in Table 8 . It is clear from table 8 that majority of the respondents $(55.88 \%)$ in experience category $\mathrm{E}_{1}$ areaware of the participation of any agency in training. An overwhelming majority of the respondents (71.19\%) in $\mathrm{E}_{2}$ category are aware of the participation of any agency in training. However a high majority of the respondents (95.33\%) in experience category $\mathrm{E}_{3}$ arenot aware on the issue of participation of outside agency in training. To test that no significant difference exists among the respondents of the various experience categories, the chi-square test has been applied. The calculated value of chi-square $\left(\chi^{2}=85.79\right)$ states that there is a significant difference in awareness among respondents of different categories of educational qualification on the issue of participation of outside agency in training. 


\section{Job satisfaction among the Marketing Functionaries}

The respondents were asked to give their opinion on 5 point "likert scale" regarding different aspects of their job and their responses are recorded in Table 9.

Table 9: Opinion of Respondents Regarding Different Aspects of Job

\begin{tabular}{|c|c|c|c|c|c|}
\hline \multirow[t]{2}{*}{ Aspects of Job } & \multicolumn{5}{|c|}{ Responses of the respondents } \\
\hline & $\begin{array}{l}\text { Highly } \\
\text { satisfied }\end{array}$ & Satisfied & $\begin{array}{l}\text { Neither } \\
\text { satisfied nor } \\
\text { dis-satisfied }\end{array}$ & Dissatisfied & $\begin{array}{l}\text { Highly } \\
\text { dissatisfied }\end{array}$ \\
\hline Compensation & $\begin{array}{l}34 \\
(17.00)\end{array}$ & $\begin{array}{l}110 \\
(55.00)\end{array}$ & $\begin{array}{l}27 \\
(13.50)\end{array}$ & $\begin{array}{l}21 \\
(10.50)\end{array}$ & $\begin{array}{l}8 \\
(4.00)\end{array}$ \\
\hline Working Hours & $\begin{array}{l}30 \\
(15.00)\end{array}$ & $\begin{array}{l}100 \\
(50.00)\end{array}$ & $\begin{array}{l}30 \\
(15.00)\end{array}$ & $\begin{array}{l}23 \\
(11.50)\end{array}$ & $\begin{array}{l}17 \\
(8.50)\end{array}$ \\
\hline Opportunities For Promotion & $\begin{array}{l}42 \\
(21.00)\end{array}$ & $\begin{array}{l}115 \\
(57.50)\end{array}$ & $\begin{array}{l}26 \\
(13.00)\end{array}$ & $\begin{array}{l}10 \\
(5.00)\end{array}$ & $\begin{array}{l}7 \\
(3.50) \\
\end{array}$ \\
\hline Fairness in Performance Appraisal System & $\begin{array}{l}30 \\
(15.00)\end{array}$ & $\begin{array}{l}100 \\
(50.00)\end{array}$ & $\begin{array}{l}36 \\
(18.00)\end{array}$ & $\begin{array}{l}19 \\
(9.50)\end{array}$ & $\begin{array}{l}15 \\
(30.00)\end{array}$ \\
\hline $\begin{array}{l}\text { Behaviour/Cooperation of office staff with } \\
\text { the marketing personnel }\end{array}$ & $\begin{array}{l}35 \\
(17.50)\end{array}$ & $\begin{array}{l}106 \\
(53.00)\end{array}$ & $\begin{array}{l}28 \\
(14.00)\end{array}$ & $\begin{array}{l}20 \\
(10.00)\end{array}$ & $\begin{array}{l}11 \\
(5.50)\end{array}$ \\
\hline Independence Associated With Your Work & $\begin{array}{l}31 \\
(15.50)\end{array}$ & $\begin{array}{l}102 \\
(51.00)\end{array}$ & $\begin{array}{l}36 \\
(18.00)\end{array}$ & $\begin{array}{l}22 \\
(11.00)\end{array}$ & $\begin{array}{l}9 \\
(4.50)\end{array}$ \\
\hline Recognition for Work Accomplished & $\begin{array}{l}29 \\
(14.50)\end{array}$ & $\begin{array}{l}118 \\
(59.00)\end{array}$ & $\begin{array}{l}26 \\
(13.00)\end{array}$ & $\begin{array}{l}16 \\
(8.00)\end{array}$ & $\begin{array}{l}11 \\
(5.50)\end{array}$ \\
\hline Support from Supervisors & $\begin{array}{l}29 \\
(14.50)\end{array}$ & $\begin{array}{l}96 \\
(48.00)\end{array}$ & $\begin{array}{l}43 \\
(21.50)\end{array}$ & $\begin{array}{l}22 \\
(11.00)\end{array}$ & $\begin{array}{l}10 \\
(5.00)\end{array}$ \\
\hline
\end{tabular}

Source: Primary Survey

Figures in parenthesis are percentages

Table 9 reveals that majority of the respondents working in life insurance industry feel that they get promotions in time $(78.50 \%)$. Nearly 73.50 per cent of the respondents feel that life insurance companies recognize the work accomplished by them. Approximately 72 per cent of the respondents are satisfied from working hours. The same proportion of the respondents $(72.00 \%)$ is satisfied with the compensation. Majority of respondents are satisfied from behavior of the staff with the marketing personnel (70.50\%). A high proportion of respondents feel that they are independent in their work $(66.50 \%)$. A big proportion of respondents feel that there is no discrimination in the performance appraisal system of life insurance companies and feel that performance appraisal system of life insurance companies is fair (65.00) and they get support from supervisors $(62.50 \%)$. To ascertain the effect of Educational qualification and experience on different aspects of job,weighted average scores have been calculated by assigning weights as +2 , for highly satisfied, +1 satisfied, 0 for neither satisfied nor dissatisfied, -1 for dissatisfied and -2 for highly dissatisfied. These scores are presented in Table 10.

Weighted Average Scores representing Educational Qualification and Experience Satisfaction Level of Respondents Regarding Different Aspects of Job

\begin{tabular}{|c|c|c|c|c|c|c|}
\hline \multirow[t]{2}{*}{ Aspects of Job } & \multicolumn{3}{|c|}{ Educational Qualification } & \multicolumn{3}{|c|}{ Experience (in Years) } \\
\hline & $\begin{array}{l}\text { Under Graduate } \\
\left(Q_{1}\right)\end{array}$ & $\begin{array}{l}\text { Graduate } \\
\left(\mathrm{Q}_{2}\right)\end{array}$ & $\begin{array}{l}\text { Post-Graduation or } \\
\text { Professional } \\
\left(Q_{3}\right)\end{array}$ & $\begin{array}{l}1-3 \\
\left(E_{1}\right)\end{array}$ & $\begin{array}{l}3-5 \\
\left(E_{2}\right)\end{array}$ & $\begin{array}{l}5 \text { and above } \\
\left(\mathrm{E}_{3}\right)\end{array}$ \\
\hline Compensation & 0.21 & 1.03 & 0.33 & 0.94 & 0.79 & 0.57 \\
\hline Working Hours & 0.57 & 0.28 & 0.84 & 0.67 & 0.98 & 0.20 \\
\hline Opportunities For Promotion & 0.58 & 0.77 & 1.11 & 0.26 & 1.11 & 0.93 \\
\hline $\begin{array}{l}\text { Fairness in Performance Appraisal } \\
\text { System }\end{array}$ & 0.74 & 0.63 & 0.39 & 0.29 & 0.61 & 0.60 \\
\hline $\begin{array}{l}\text { Behaviour/Cooperation of office } \\
\text { staff with the marketing personnel }\end{array}$ & 0.78 & 0.56 & 0.80 & 0.08 & 0.59 & 0.90 \\
\hline $\begin{array}{lll}\text { Independence } & \text { Associated } & \text { With } \\
\text { Your Work } & & \\
\end{array}$ & 0.10 & 0.58 & 0.82 & -0.32 & 0.88 & 0.77 \\
\hline $\begin{array}{lll}\text { Recognition } & \text { for } & \text { Work } \\
\text { Accomplished } & & \\
\end{array}$ & 0.21 & 0.49 & 1.11 & 0.17 & 0.68 & 0.86 \\
\hline Support from Supervisors & 0.84 & 0.28 & 0.90 & 0.029 & 1.03 & 0.47 \\
\hline $\begin{array}{l}\text { Kendall's Coefficient } \\
\text { Concordance }(W)\end{array}$ & \multicolumn{3}{|c|}{$\begin{array}{l}W=0.1767 \\
\text { Chi-square }=3.7108 \\
\text { degree of freed } 0 m=7 \\
p=0.81 \\
\text { insignificant at } 5 \text { per cent level of significance }\end{array}$} & \multicolumn{3}{|c|}{$\begin{array}{l}W=0.2116 \\
\text { Chi-square }=4.4444 \\
\text { degree of freedom }=7 \mathrm{p}=0.72 \\
\text { insignificant at } 5 \text { per cent level of } \\
\text { significance }\end{array}$} \\
\hline
\end{tabular}

Source: Primary Survey

DOI: 10.9790/487X-1906021021

www.iosrjournals.org

18 | Page 
It is depicted in table 10 that the respondents in category $\mathrm{Q}_{1}$ are less satisfied from compensation as compared to respondents in category $\mathrm{Q}_{2}$ and $\mathrm{Q}_{3}$. The respondents in $\mathrm{Q}_{3}$ category are more satisfied from working hours as compared to respondents in other categories. The respondents in category $\mathrm{Q}_{1}$ and $\mathrm{Q}_{2}$ are more satisfied thanthe respondents in $\mathrm{Q}_{3}$ category from performance appraisal system of life insurance companies. The respondents in category $\mathrm{Q}_{1}$ feel that they are less independent in terms of work as compared to $\mathrm{Q}_{2}$ and $\mathrm{Q}_{3}$ category of respondents. The respondents in category $\mathrm{Q}_{2}$ feel that they get less support from their supervisors as compared to respondents in category $\mathrm{Q}_{1}$ and $\mathrm{Q}_{3}$. To test that no significant concurrence of rankings exists among the respondents in different educational qualification categories on different aspects of job,Kendall Coefficient of Concordance has been applied.The Kendall Coefficient of Concordance ( $\mathrm{W}=0.1767)$ suggests that there is no significant concurrence of rankings exist among the respondents in different educational qualification categories on different aspects of job. Thus the null hypothesis (Ho) is accepted at 5 per cent level of significance.

It is revealed from the same table that the respondents in experience category $\mathrm{E}_{1}$ are dissatisfied from recognition for work accomplished by them. These respondents are also very less satisfied from behaviour or cooperation of office staff with them and from the support of supervisors. The respondents in category $\mathrm{E}_{2}$ are more satisfied from opportunities for promotion and the support of supervisors than the respondents in $E_{1}$ and $E_{3}$ category. The respondents in category $\mathrm{E}_{3}$ are less satisfied from working hours and support from supervisors. To test that no significant concurrence of rankings exists among the respondents in different experience categories on different aspects of job, Kendall Coefficient of Concordance has been applied. The Kendall Coefficient of Concordance $(\mathrm{W}=0.2116)$ suggests that there is no significant concurrence of rankings exist among the respondents in different experience categories on different aspects of job. Thus the null hypothesis (Ho) is accepted at 5 per cent level of significance.

The sector-wise weighted average scores have also been calculated by assigning weights as +2 , for highly satisfied, +1 satisfied, 0 for neither satisfied nor dissatisfied, -1 for dissatisfied and -2 for highly dissatisfied. These scores are presented in Table 11. Table 11 reveals that the respondents from both the sectors are satisfied from all the aspects of job. However, the respondents from public sector are highly satisfied from compensation $(0.9800)$ and independence associated with work (0.9800) followed by working hours $(0.8900)$, fairness in performance appraisal system (0.8300), opportunities for promotion (0.8200) and behavior of the staff with the marketing personnel $(0.7700)$. On the other hand the respondents from private sector are highly satisfied from recognition for work accomplished (0.9500) and opportunities for promotion (0.9300).

Table 11: Weighted Average Scores representing Sector-wise Satisfaction Level of Respondents Regarding Different Aspects of Job

\begin{tabular}{|c|c|c|c|}
\hline \multirow[t]{2}{*}{ Aspects of Job } & \multicolumn{2}{|l|}{ Sector } & \multirow[t]{2}{*}{ Total } \\
\hline & Public & Private & \\
\hline Compensation & 0.9800 & 0.4300 & 0.7050 \\
\hline Working Hours & 0.8900 & 0.1400 & 0.5150 \\
\hline Opportunities For Promotion & 0.8200 & 0.9300 & 0.8750 \\
\hline Fairnessin Performance Appraisal System & 0.8300 & 0.2800 & 0.5550 \\
\hline $\begin{array}{l}\text { Behaviour or Cooperation of office staff with } \\
\text { the marketing personnel }\end{array}$ & 0.7700 & 0.5700 & 0.6700 \\
\hline Independence Associated With Your Work & 0.9800 & 0.2600 & 0.6200 \\
\hline Recognition for Work Accomplished & 0.4300 & 0.9500 & 0.6900 \\
\hline Support from Supervisors & 0.6200 & 0.5000 & 0.5600 \\
\hline $\begin{array}{l}\text { Kendall's Tau Coefficient } \\
(\tau)\end{array}$ & \multicolumn{2}{|c|}{$\begin{array}{l}-0.54 p=0.08 \text { insignificant at } 5 \text { per cent level of } \\
\text { significance }\end{array}$} & \\
\hline
\end{tabular}

Source: Primary Survey

To Test that no significant agreement exists between public and private sector respondents on job satisfaction, Kendall Tau rank correlation test has been applied. The Kendall Tau rank correlation test $(\tau=-0.54)$ suggests that there is no significant agreement between public and private sector respondents on job satisfaction at 5 per cent level ofsignificance.

\section{Summary And Suggestions}

From the above discussion it is concluded that human resource development practices focuses on enhancing learning culture in the life insurance companies. The public and private life insurance companies have their own HRD departments which are responsible for preparing the training and development programmes for their sales force. The life insurance companies preferably train their sales personnel by providing them study material at 
Human Resource Development Practices: A Study of Public and Private Life Insurance Companies

frequent intervals of time to update the sales force on recent changes occurring in the market. The lectures in the class room commonly referred to as class room training is another popular method of training in the industry. The life insurance companies also give case studies to sales personnel in order to improve their problem solving and decision making ability. A significant difference is also observed in awareness among respondents on the issue of participation of outside agency in training. It is also interesting that the respondents with post graduate qualification are least aware while those with qualification below graduation were comparatively more awareon the issue of participation of outside agency in training.Further, those who are less experienced are comparatively more aware on the issue of participation of outside agency in training than those who are having more experience It is found in the study that respondents are less satisfied from support of supervisors; it is therefore suggested that supervisors should be given strict instructions by the management of life insurers to support and help marketing personnel of the company. It will enhance the interest of marketing functionaries and thus more life insurance business can be procured by them. Some of the respondents are less satisfied from the behavior and cooperation of office staff with the marketing personnel. Therefore the attempts should be made by life insurance companies to make harmonious relationships among office staff and marketing functionaries. It is also suggested that in the public sector more emphasis should be laid on practical training rather than class room training. The agents should also be fully equipped with competitive marketing strategy to function in a competitive market because many of them might have worked in monopoly market structure. Since the public sector respondents are less satisfied from the independence of doing work, it is therefore suggested that the public sector should provide more independence to sales force in their assignments. The private life insurers should strictly utilize the services of National Skill Development Council (NSDC) and Banking Financial Services and Insurance Sector Skill (BFSI) in a phased manner in order to improve training practices. Since the private sector's respondents are less satisfied from working hours and performance appraisal system of private insurers, it is therefore suggested that private sector life insurers should also try to improve their performance appraisal system in order to improve goodwill among marketing functionaries. The private sector should also try to provide more flexibility in the working hours of marketing functionaries. IRDA is the regulatory body for insurance sector. However, it should also undertake independent studies in the industry to know the various aspects or problems related to the marketing functionaries. Such studies can also be undertaken by educational institutions which can be financed by IRDA.

[1] Agadi, Ramesh, Bais, Singh, Santosh, "Problems of HRD in Insurance Sector", Journal of Contemporary Research in Management, 2008, pp.33-48.

[2] Bais, Singh, Santosh, "Human Resource Development (HRD) In Insurance Sector (A Study with Special Reference to Life Insurance Corporation of (LIC) India)",EXCELInternational Journal of Multidisciplinary Management Studies, Vol.1 Issue 3, 2011,pp.196-227.

[3] Patre, Smruti, Rahul, Gawande, Vinod, "An Exploratory Study on level of Job Satisfaction and Intent to Leave Among Sales Workforce of Private Sector Insurance Companies with Reference to Nagpur City" Journal of Strategic Human Resource Management, Volume 1 Issue 3 October 2012,pp.39-50.

[4] Kaur, Hardeep, "Job Satisfaction during Recession Period: A Study on Public \& Private Insurance in Punjab", International Journal of Advanced Research in Management and Social Sciences, Vol. 1, No. 1, 2012, pp.24-42.

[5] Singh, Anita, "Job Satisfaction In Insurance Sector: An Empirical Investigation", International Journal of Engineering and Management Science, VOL.3 (4), 2012, pp.425-432.

[6] Yadav, Babita, Gour, Singh, Hari, Rokade, Varsha, "Analytical Study on Employee Job Satisfaction of HDFC Standard Life Insurance", International Journal in Management and Social Science, Vol.2, Issue-11, 2014, pp.198-218.

[7] Tiwari, Usha, "An Analysis of Job Satisfaction And Its Impact on Employees Performance at Life Insurance Corporation (LIC) of India”, Abhinav International Monthly Refereed Journal of Research in Management \& Technology, Vol. 3, Issue 11 2014, pp.15-21.

[8] Dolai, Dolly, "Perception of Employees on HRD Climate in Insurance Sector: Public vs. Private" PARIPEX - Indian Journal of Research, Volume : 4,Issue 7, 2015,pp.328-330

[9] Dash, Swetapadma, Das, Kumar, Kishore, "HRD Climate in Insurance Sector: A Study with Special Reference to Life Insurance Corporation of (LIC) India", International Journal of Research in IT and Management, Vol. x, Issue x, August 2016, pp. 5-18.

[10] Kothari, C.R., Research Methodology Methods and Techniques, New Age International (P) Limited Publishers, New Delhi, Second Revised Edition, 2004.

\section{Internet Sources}

[11] http://www.pondiuni.edu.in/sites/default/files/HRDt200813.pdf

[12] https://books.google.co.in/books?id=nCkXMZjs0XcC\&printsec=frontcover\&dq=job+satisfaction\&hl=en\&sa=X\&redir_esc=y\#v=onepag $\mathrm{e} \& \mathrm{q}=\mathrm{job} \% 20$ satisfaction $\& \mathrm{f}=$ false

[13] https://books.google.co.in/books?id=4IdbmX4pDpkC\&pg=PA180\&dq=job+satisfaction+definition\&hl=en\&sa=X\&ved=0ahUKEwjk2au 4n6nTAhVMpo8KHXlrC2oQ6AEIQzAG\#v=onepage \&q=job\%20satisfaction\%20definition\&f=false

[14] https://www.iciciprulife.com/content/dam/icicipru/aboutus/FinancialInformation/AnnualReports/FY2015.pdf

[15] https://www.hdfclife.com/iwov-resources/pdf/financial/2015-16/public/HDFC-Life-Annual-Report-FY-2015-16.pdf

[16] https://www.bajajallianzlife.com/pdf/annual-report/BALIC-Annual-Report-15-16.pdf

[17] https://www.bajajallianzlife.com/pdf/annual-report/BALIC-Annual-Report-15-16.pdf

[18] https://www.licindia.in/getattachment/Bottom-Links/annual-report/LIC-Annual-Report-2015-16.pdf.aspx 
Human Resource Development Practices: A Study of Public and Private Life Insurance Companies

[19] https://www.licindia.in/Bottom-Links/annual-report/LIC_ANNUAL_-REPORT_2014_15-pdf

[20] https://www.licindia.in/

[21] https://www.hdfclife.com/

[22] https://www.bajajallianz.com/Corp/new-index.jsp 